\title{
Book Review - New Literacy Narratives from an Urban University: Analyzing Stories About Reading, Writing, and Changing Technologies, by Sally Chandler With Angela Castillo, Maureen Kadash, Molly D. Kenner, Lorena Ramirez, and Ryan J. Valdez
}

\section{Gwen Gorzelsky - Wayne State University}

New Literacy Narratives from an Urban University: Analyzing Stories About Reading, Writing, and Changing Technologies, by Sally Chandler with Angela Castillo, Maureen Kadash, Molly D. Kenner, Lorena Ramirez, and Ryan J. Valdez. New York: Hampton Press, 2013. 364 pp.

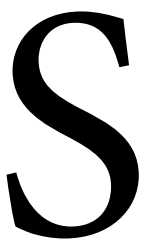

everal of the pieces in LiCS' inaugural issue warn against easy valorization of marginalized groups' community-based literate practices (Flannery; Horner; Parks; Trainor). Bruce Horner cautions that fetishizing these and digital literate practices re-instates the autonomous model of literacy critiqued by new literacy studies scholars. Such fetishization presumes that liberatory power inheres in these literacies. This fetishization fails to join marginalized groups in using literacy to transform inequitable social relations (Horner 5-6). Similarly, Kathryn Flannery affirms community-based literate practices but argues that compositionists must emphasize the value of academic literacies, as do Steve Parks and Jennifer Seibel Trainor.

However, Brian Street contends that recognizing the social character of literacies doesn't automatically re-instate the autonomous model. He recommends examining the contextually shaped, social nature of academic literacies and the challenges students face in acquiring them, because knowledge about them is often tacit. He notes that genre studies scholarship has begun to bridge literacy studies with composition studies (39-40), showing the significant extent to which "academic literacy" is field-specific. Allan Luke echoes Street by stressing that literacy studies approaches can help marginalized students work with linguistic and other differences in learning specific academic and digital literacies.

In the spirit of Luke's and Street's arguments, New Literacy Narratives from an Urban University, by literacy researcher Sally Chandler, with five student co-authors, suggests a composition pedagogy grounded in literacy studies. To do so, it showcases the hybrid, transitional genres advocated by Flannery, Horner, Parks, and Trainor.

The book analyzes the co-authors' literacy narratives for two larger purposes. First, it illuminates marginalized students' experiences of literacy acquisition, showing how political, economic, and social factors shape this process and how learners exert agency within it. Second, because its analyses are embedded in subsequent reflections and theoretical discussions, the co-authors show 
how participatory action research (PAR) on literacy narratives reveals factors unrecognized by other methods and provides a compelling approach to literacy instruction.

These purposes coalesce in the book's central argument: that its version of PAR, which uses narrative theory to analyze literacy narratives, extends existing research methods for investigating new literacies and engages students in literacy learning (13). The book addresses literacy researchers and teachers, but Chandler explicitly positions it as targeting students, too, noting that because it "was envisioned as a teaching book," it includes long passages from co-authors' interview transcripts and reflections that "are meant to provide the kinds of detailed materials that can be used as practice data" (12). While some tension may result from speaking to such diverse audiences, that tension is ultimately productive. The book both affords a rich resource for post-secondary literacy instruction and raises provocative methodological questions for researchers.

By presenting and analyzing bits of Chandler's literacy narrative, Chapter One, "New Literacies, Story Forms, and Literacy Narratives: Theory and Practice," introduces students to key concepts in literacy studies and narrative analysis. By showing how Chandler's middle-class, rural background shaped her initial perceptions of her students, it explains concepts like the "literacy myth" and the socially constructed, ideological nature of literacy. It also examines an excerpt from a co-author's interview transcript to introduce key aspects of the research methods that the book enacts and teaches. Through a detailed description of these methods, Chapter Two, "Participatory Research and Active Interviewing," explains both the practices and the larger epistemological and ethical issues involved. By describing co-authors' modifications of existing PAR models to fit their goals and local constraints, it raises useful questions about PAR's understanding of social justice, particularly around questions of how researcher and participants jointly shape research goals. As its title suggests, Chapter Three focuses on "Narrative Analysis: Research Process, Concepts and Methods." Showing how co-authors analyzed their narratives, the chapter guides readers through research methods and highlights methodological issues, such as when to privilege examination of formal features and when to focus on interactive, contextual features.

The first of five chapters that each present one co-author's literacy narrative, Chapter Four, "Forbidden Visits to MiGente.Com," analyzes the surface stories and deeper themes in young adult student Lorena Ramirez' literacy experiences. It illustrates how Ramirez, the bilingual daughter of Colombian immigrants, achieves agency through narrative structures that enabled her to "analyze the meaning of experiences [so that] negative elements are recast in positive ways" (134). Chapter Five, "Reinventing Self: Story Forms and Literate Identity," presents literacy narratives by Molly Kenner, a returning adult African American student. It reveals an interplay between some narratives in which Kenner presents herself as successfully in control, during her primary and secondary education and in her personal use of technology, and others in which she presents herself as vulnerable, uncertain, and struggling, during her early attempts at higher education and in her use of technology in educational settings, "where she confronted literacies outside her current experience" (160). Kenner and Chandler suggest that reflective literacy narratives may illuminate hidden learning issues and help students negotiate the identity conflicts often connected to learning new literacies (165-6).

In Chapter Six, "Stories as Evidence of How Literate Identities Change and Grow," returning 
adult student Maureen Kadash and Chandler illustrate the roles different narrative types play in identity (re)construction. Kadash and Chandler suggest that composition courses might help students use literate practices to (re)construct identity by integrating literacy narrative writing prompts with assignments that ask students to take part in documented conversations and to analyze both types of work. The potential value of analyzing one's own literacy narratives emerges further in Chapter Seven, "Making Room for Multiple Literacies." Co-author Ryan Valdez, a young adult master's student in English and the son of Filipino immigrants, uses such analyses to recognize how working-class literate practices led him both to devalue the digital literacies in which he excelled and to struggle with graduate work, despite his success as an undergraduate English major. Noting that students may need to address identity conflicts tied to literacy work more broadly, Valdez and Chandler argue that if digital natives are to import their online literate strategies into print literacies, they may need "new story structures to support changes that allow them to integrate these two conflicting ideologies" (227). The importance of such revised story structures is reinforced by Chapter Eight, "Online Selves and the Mediation of Identity Development," which illustrates young adult co-author Angela Castillo's negotiation of a Filipino and American cultures through her use of online spaces for adolescent identity development and the power of negative mainstream narratives to shape even literacy researchers' initial responses to teens' digital media use.

By examining the benefits the research process offered to all co-authors, Chapter Nine, "New Literacies Research and Collaborative, Reflective Narrative Analysis," highlights the book's potential relevance to graduate and undergraduate courses investigating literacy. While acknowledging that "increased awareness of language choices and narrative habits does not [automatically enable] students to step seamlessly into academic discourses" (300), the chapter stresses that such awareness can foster moments when small shifts in storytelling link to larger changes in literacy identities and when learners turn seemingly repressive dominant narratives to empowering ends. By extending literacy studies methods used by Deborah Brandt and by Cynthia Selfe and Gail Hawisher, New Literacy Narratives provides tools for writing instructors, particularly those teaching marginalized students. It suggests that teachers ask students to explore academic literacies as Street advocates by composing multi-layered texts through which writers not only construct but reflectively examine stories of learning and identity. This integration of narrative, reflection, and qualitative methods exemplifies the evolving, hybrid genres recommended by Flannery, Horner, Parks, and Trainor. 


\section{WORKS CITED}

Brandt, Deborah. Literacy in American Lives. Cambridge: Cambridge UP, 2001.

Flannery, Kathryn. “Babies and Bath Water." Literacy in Composition Studies 1.1 (2013): 33-37. Web. 18 Jan. 2014.

Horner, Bruce. “Ideologies of Literacy, 'Academic Literacies,' and Composition Studies." Literacy in Composition Studies 1.1 (2013): 1-9. Web. 18 Jan. 2014.

Luke, Allan. “Undoing Composition?” Literacy in Composition Studies 1.1 (2013): 70-74. Web. 18 Jan. 2014.

Parks, Steve. "Beginnings of a Polemic: Shaking the Borders of a Literate Education." Literacy in Composition Studies 1.1 (2013): 42-44. Web. 18 Jan. 2014.

Selfe, Cynthia L. and Gail E. Hawisher. Literate Lives in the Information Age: Narratives of Literacy from the United States. Mahwah, NJ: Erlbaum, 2004.

Street, Brian V. “Symposium Comments." Literacy in Composition Studies 1.1 (2013): 38-41. Web. 18 Jan. 2014.

Trainor, Jennifer Seibel. "Moving Beyond Place in Discussions of Literacy." Literacy in Composition Studies 1.1 (2013): 45-47. Web. 18 Jan. 2014. 